\begin{tabular}{|c|c|}
\hline \multirow{3}{*}{ 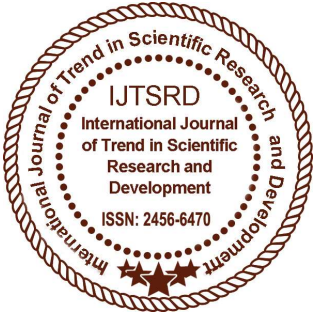 } & $\begin{array}{l}\text { International Journal of Trend in Scientific } \\
\text { Research and Development (IJTSRD) }\end{array}$ \\
\hline & UGC Approved International Open Access Journal \\
\hline & ISSN No: 2456 - 6470 | www.ijtsrd.com | Volume - 1 | Issue - 5 \\
\hline
\end{tabular}

\title{
Evaluation of Technological Competences, Case Study: Teachers of Superior Level
}

\author{
Ramírez Castañeda Iscander A. \\ Instituto Tecnológico de Tláhuac II \\ Delegación Tláhuac, Ciudad de \\ México, México
}

\author{
Velázquez Reyes Sara M. \\ Instituto Tecnológico de la Laguna \\ Torreón, Coahuila, México
}

García Carrillo María C. Instituto Tecnológico de la Laguna

Torreón, Coahuila, México

\begin{abstract}
The training of teachers is the way forward for the incorporation of the media into the field of education. Personal attitudes towards $\mathrm{TIC}^{\prime} \mathrm{s}$ and their way of influencing the interest and motivation of teachers to form and to put into practice new tools should be assessed. The objective of the present research is to evaluate the digital competences in the professors of superior level. A reliability of $95 \%$ and a maximum allowed error of $5 \%$ were used. The instrument proposed by Briones (2013) was used. The results show that more than $50 \%$ of teachers surveyed are aware of the subject studied but only $15 \%$ know the benefits of implementing $\mathrm{TIC}^{\prime} \mathrm{s}$ in their teaching practice.
\end{abstract}

Keywords-- Evaluation, technological competences and teaching practice

\section{INTRODUCTION}

The current technological paradigm of Information and Communication Technologies (TIC's) in modern society, specifically the last three decades of the twentieth century and what goes of the present, continues to challenge society in the use and disposal of the computer And the Internet in daily, professional and learning tasks (Angulo, Mortis, Pizá y García, $\mathrm{s} / \mathrm{f})$.

Diaz (2009) mentions that it is a fact that in recent decades has increased qualitatively and quantitatively the use of Information and Communication
Technologies in society, which is leading to a transformation of this.

According to Levis (2011), the presence of Information and Communication Technologies (TIC's) in almost all activities, both public and private, have become a challenge for education, because we are constantly exposed To stimuli of the television and the internet, with special importance in the formation of children and young people, being of daily use, the cell phone, the computer, video game console, Internet, DVD and MP3 players, and especially the television. The group of educational technology (2017) points out that the evaluation of TIC's can serve to achieve different functions, ranging from analyzing them for acquisition, to see their effects, to adapt the material to the characteristics of the potential receivers, to improve their aspects Technical and aesthetic, modify their production and postproduction, or study their profitability and economic viability.

ELMO (2012) mentions that the main advantages of the $\mathrm{TIC}^{\prime} \mathrm{s}$ tools for education are the following:

$>$ Through TIC's, images can be easily used in teaching and improving students' retentive memory.

$>$ Through $\mathrm{TIC}^{\prime} \mathrm{s}$, teachers can easily explain complex instructions and ensure student understanding. 
Through ICTs, teachers can create interactive classes and so the classes are more enjoyable, which could improve student attendance and concentration.

\section{GENERAL OBJECTIVE}

Assessment of technological competences in higher level teachers in order to guide training routes that allow them to optimally integrate the resources and technological tools available in the classroom.

\section{SPECIFIC OBJECTIVES}

Know the conceptualization of the topic of technological competences.

$>$ Understand the hierarchy of the technological competency process in higher level teachers.

$>$ Analyze the process of technological competence in higher education teachers.

$>$ Evaluate the results obtained from the analysis of the technological competences in the professors of superior level to propose improvements to the same one.

\section{JUSTIFICATION}

According to the 2011 Education Curriculum of the Secretary of Public Education (SEP) the teacher must be in permanent update and develop skills for the management and use of Information and Communication Technologies (TIC's).

For this reason a survey will be applied to higher level teachers of a Private University to assess the level of development in TIC's skills and promote strategies to improve their teaching practice. That is why it is important and is of interest the development of research in all this change according to social contexts.

\section{KIND OF INVESTIGATION}

According to the author Sampieri (2006), the research will consist of descriptive research because it seeks to specify the characteristics and important features of the phenomenon of study, analyze and discover trends of a population group.

That is, the research will collect data to be measured on the sample of the population (teachers) of higher level and the variable will be the use of Technology as a tool in the teaching-learning process.

\section{CALCULATION OF THE SIMPLE}

At this stage of research, field research, to know the number of teachers who study college it has developed. Table 1 shows the distribution of university teachers.

\section{Table 1: Example of number of teachers}

\begin{tabular}{|c|c|}
\hline Gender & Total \\
\hline Female & 28 \\
\hline Male & 22 \\
\hline
\end{tabular}

Once the study population was known, the representative sample of the study was calculated. A $95 \%$ confidence interval and a maximum allowable error of $5 \%$ were used for the investigation. The formula used was the one proposed by Dr. Bolaños (2012), which is used for finite or known populations. The formula is as follows:

$n=\left[\frac{Z_{\alpha}^{2} * N^{*} p^{*} q}{i^{2}(N-1)+Z_{\alpha}^{2} * p^{*} q}\right]$

Where:

$\mathrm{n}$ : sample size

$\mathrm{N}$ : population size

$Z$ : value corresponding to the gauss distribution, for the investigation $Z=95 \%$, which is equal to 1.96 .

$\mathrm{p}$ : expected prevalence of the parameter to be evaluated, if not known ( $p=0.5)$, which makes the sample size larger.

q: $1-p($ if $p=70 \%, q=30 \%)$

$\mathrm{i}$ : error expected to be committed if it is $5 \%, \mathrm{i}=0.05$

The development of the formula is as follows:

$$
n=\left[\frac{(1.96)^{2} * 50 * 0.5 * 0.5}{(0.05)^{2}(50-1)+(1.96)^{2} * 0.5 * 0.5}\right]=\frac{48.02}{0.1225+0.9604}=\frac{48.02}{1.0829}=44.34 \approx 45
$$


The study indicated that a population of 50 teachers with which the University counts, using 95\% reliability and 5\% error allowed will require 45 teachers for research.

\section{Research instrument used}

The survey that was used for the development of the research, is the one proposed by Briones (2013). The instrument used consists of 10 questions, which address the research topic. Figure 1 shows an example of the survey used in research.

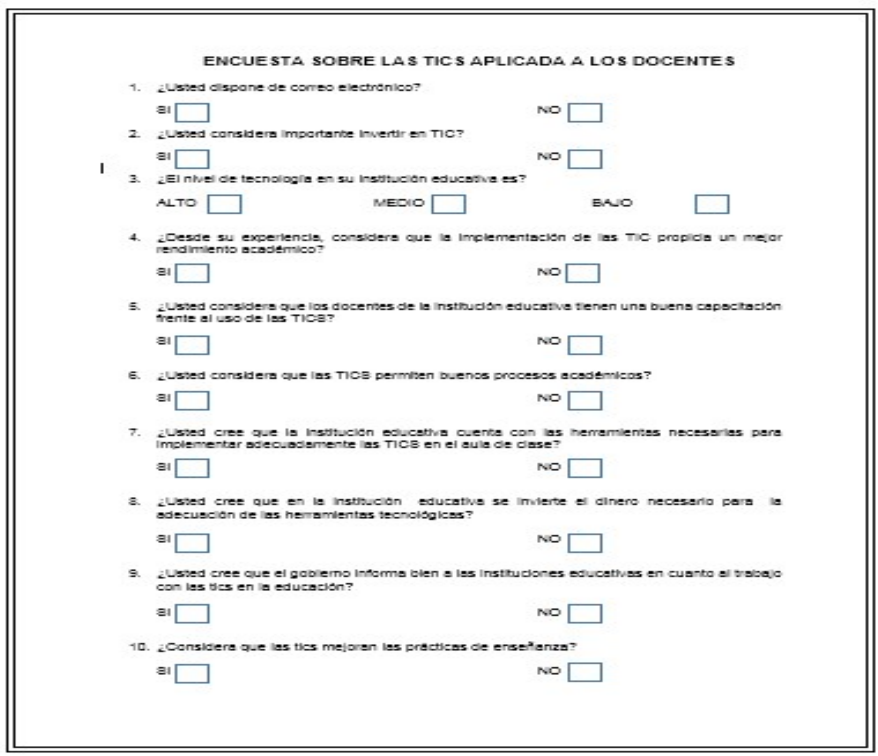

Figure 1: Sample survey used in research

\section{ANALYSIS OF DATA}

Once the surveys were applied to the representative sample of university professors, the results obtained were as follows:

$56 \%$ of the representative sample corresponds to women and $44 \%$ concerned men. Figure 2 shows an example of the afore mentioned. Figure 2 shows an example of the explained results.

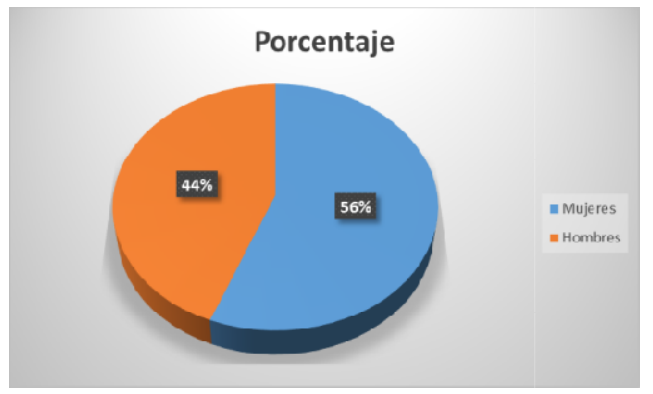

Figure 2: Example of the results explained.
For question 1, 48 teachers do have an email account and only 2 teachers do not have an email account. Figure 3 shows the results presented.

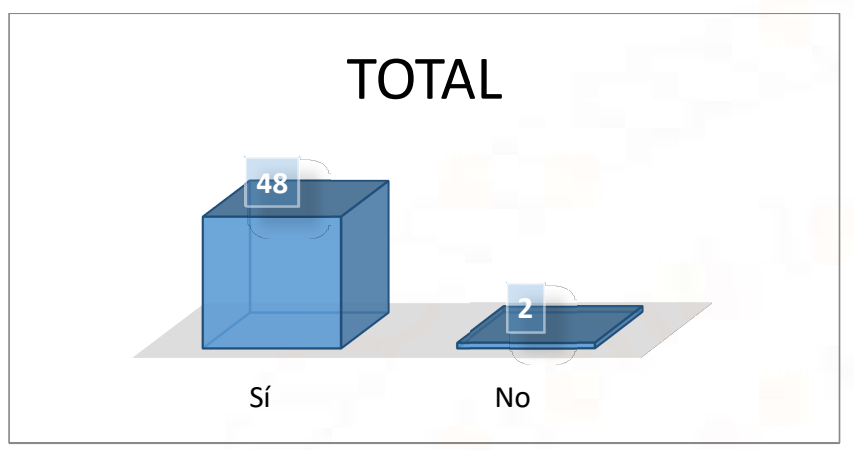

Figure 3: Example of the results presented.

For Question 2, 45 teachers have knowledge of investing in TIC's and only 5 teachers are not aware of investing in TIC's. Figure 4 shows the results presented.

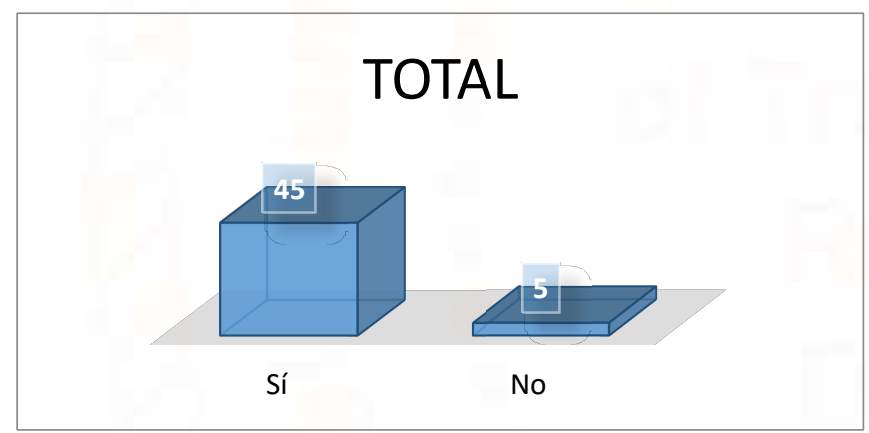

Figure 4: Example of the results presented.

For question 3, 25 teachers evaluated that the level of technology in the university is low, 15 teachers weighed that the level of technology is average and only 10 teachers evaluated that the level of technology is high. Figure 5 shows the results presented.

\section{TOTAL}

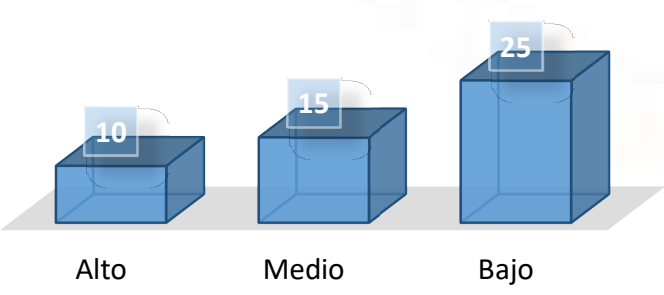

Figure 5: Example of the results presented. 
For question 4, 40 teachers think that incorporating TIC's in the classroom will lead to better academic performance. Only 10 teachers think otherwise. Figure 6 shows the above results.

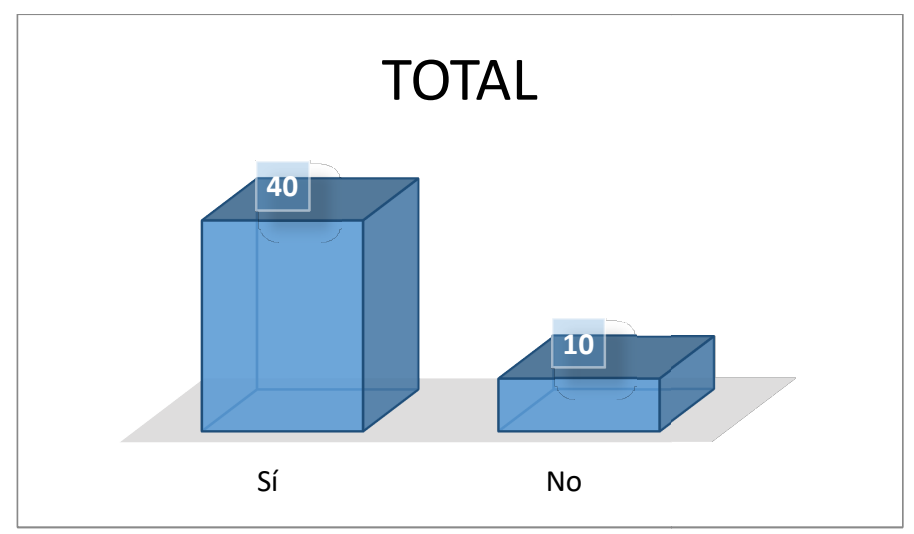

Figure 6: Example of the results presented.

For question 5, 13 teachers think that the university has a good training regarding ICTs. 35 teachers think the university offers poor training. Figure 7 shows the results mentioned.

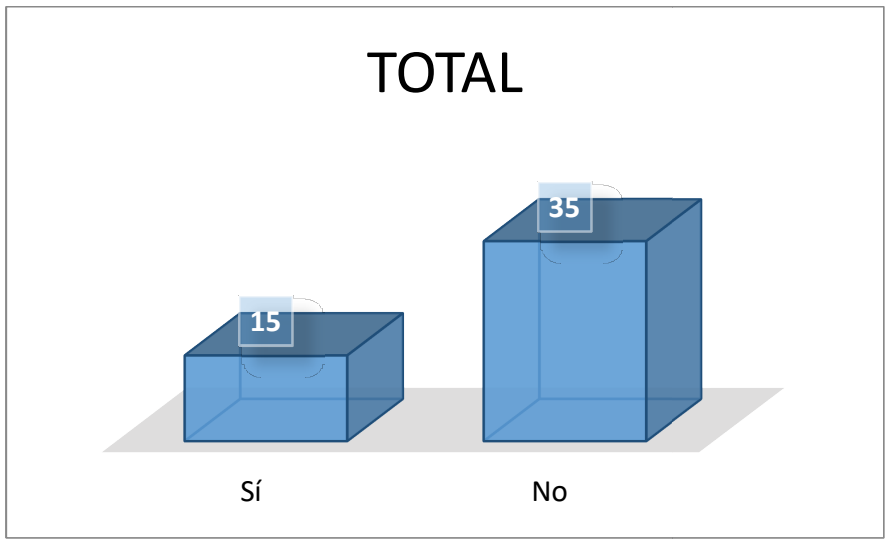

Figure 7: Example of the results presented.

For Question 6, 40 teachers think that TIC's offer good academic processes and only 10 teachers think otherwise. 8 shows an example of the results mentioned.

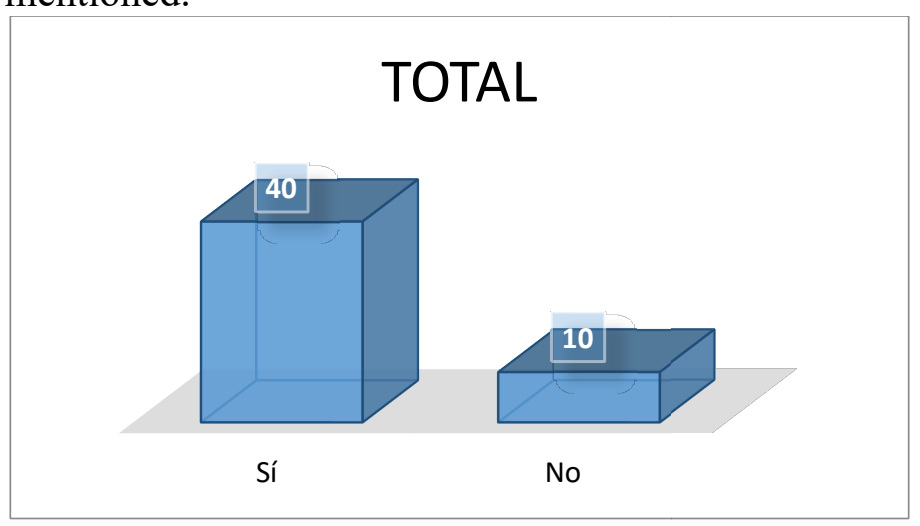

For question 7, 40 teachers think that the university has the right tools to incorporate ICT in the educational process and only 10 teachers think otherwise. Figure 8 shows an example of the results mentioned.

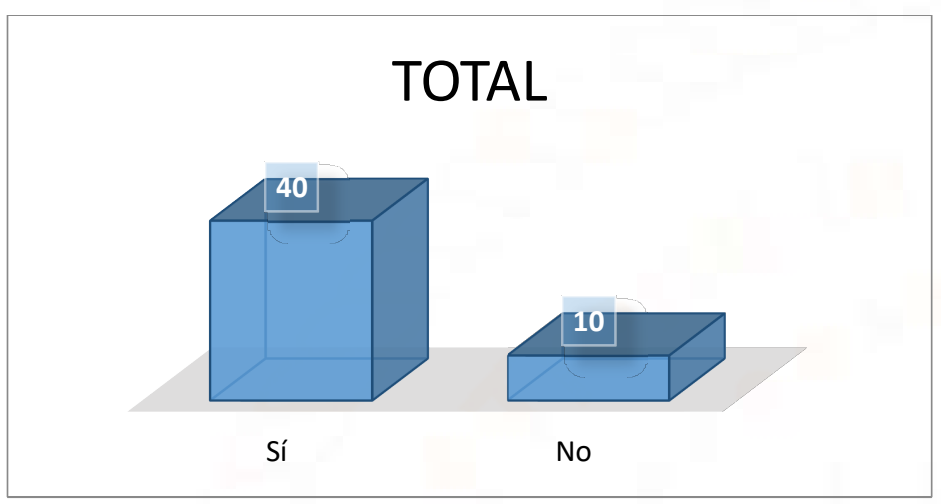

Figure 8: Example of the results presented.

For question 8,35 teachers think that the university does not invest adequately in TIC's and only 15 teachers think otherwise. Figure 9 shows an example of the results mentioned.

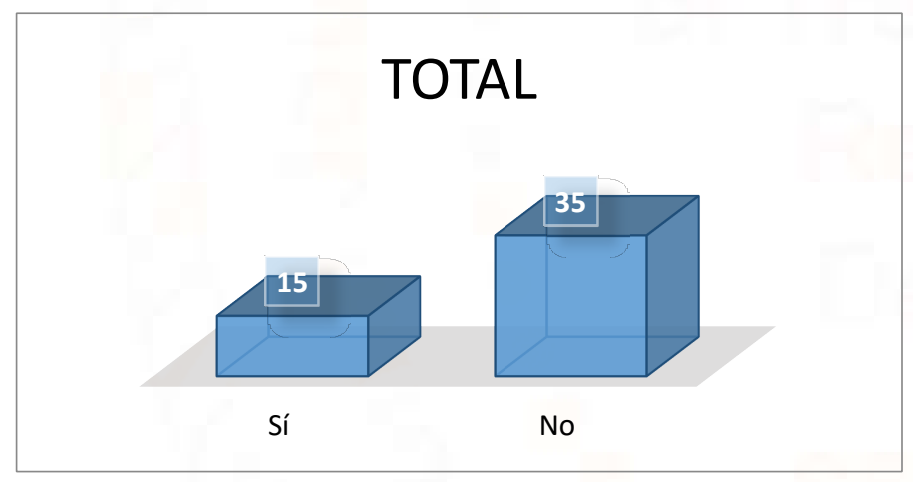

Figure 9: Example of the results presented.

For question 9, 35 teachers think that the government does not adequately inform universities about the incorporation of TIC's in the educational process and only 15 teachers think otherwise. Figure 10 shows an example of the results mentioned.

Figure 7: Example of the results presented. 


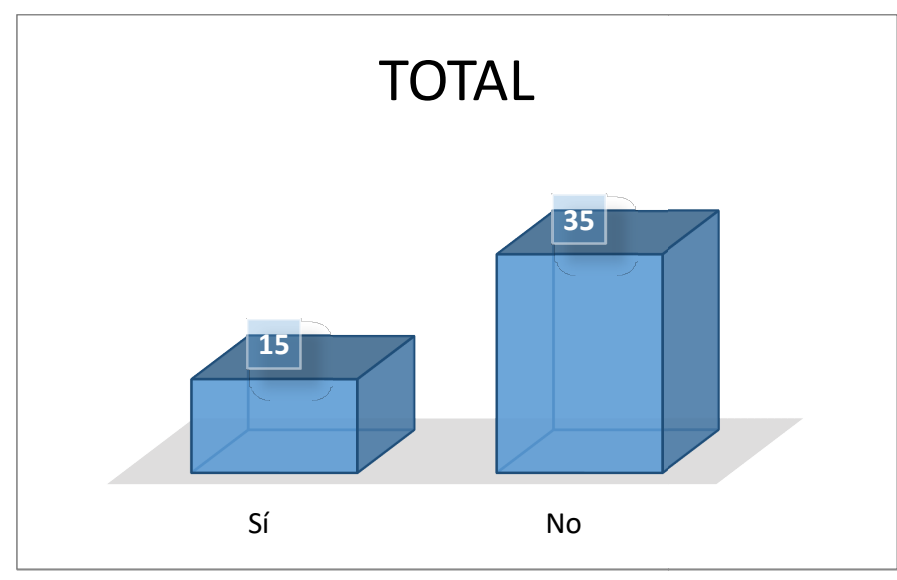

Figure 10: Example of the results presented.

For question 10, 15 teachers think that TIC's will improve teaching in the classroom and only 35 teachers think otherwise. Figure 11 shows an example of the results mentioned.

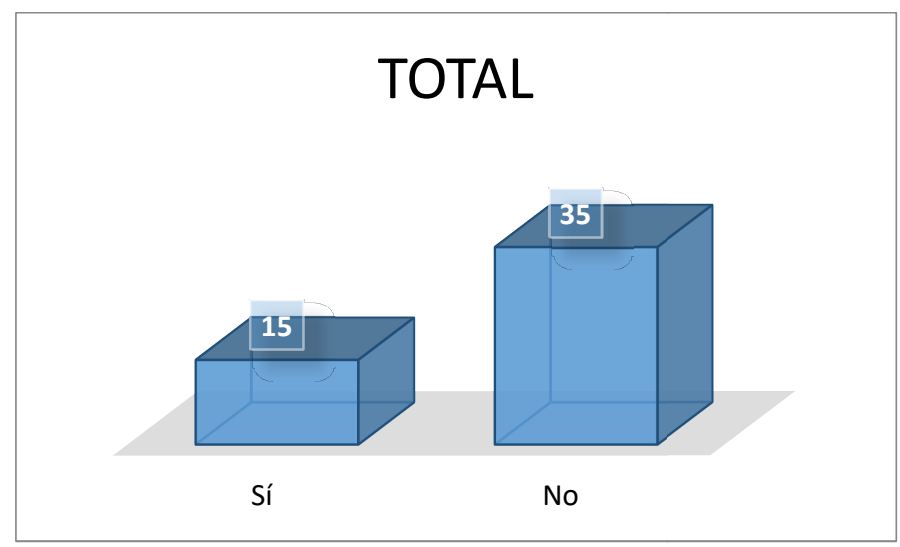

Figure 11: Example of the results presented.

\section{CONCLUSIONS}

Thanks to the study, it was possible to evaluate the digital competences of the university's higher education teachers.

It is concluded that more than $50 \%$ of teachers surveyed are aware of the subject studied but only $15 \%$ know the benefits of implementing TIC's in their teaching practice.

According to the results of the research, it is possible to conclude in a general way that the teachers show a positive attitude towards the incorporation of the TIC's in the educational process and recognize that they favor the learning of the students but the directors recognize it partially, Which attribute this benefit depending on the use that teachers give in their work in the classroom.

Thus, through the information provided, it was possible to verify that this apparent attitude in favor has not been a guarantee that they are transforming their practice or giving a more intensive use to the various applications that can be achieved through the use of the computer and the Internet.

\section{ACKNOWLEDGMENT}

M.I.I. Arturo González Torres por su asesoramiento, tutoría y dirección del proyecto.

\section{REFERENCES}

1) Angulo Armenta, J., Mortis Lozoya, S. V., Pizá Gutiérrez, R. I. y García López, R. I. (s/f). Estudio sobre competencias digitales en profesores de secundaria.

2) Bolaños Rodríguez, E. (2012). Muestra y Muestreo. Asignatura: Estadística para el Desarrollo Tecnológico. Área Académica: Gestión Tecnológica. Escuela Superior e Tizayuca. Universidad Autónoma de Hidalgo.

3) Briones Álvarez, G. E. (2013). Encuesta sobre las TIC's. Asignatura: Evaluación Educativa y Estadística. Centro Universitario Vinces. Facultad de Filosofía Letras y Ciencias. Universidad de Guayaquil.

4) Díaz, I. (2009). Las competencias TIC y la integración de las tecnologías de la información y comunicación de los docentes de la Universidad Católica del Maule. Programa de Magíster en Educación. Escuela de Postgrado. Facultad de Ciencias Sociales. Universidad de Chile. Santiago. Chile.

5) Grupo de tecnología educativa. (2017). La evaluación de las tics. Universidad de Sevilla.

6) Levis, D. (2011). Formación docente en tic: ¿el huevo o la gallina? Revista Razón y palabra. Número 63. México.

7) Sampieri, H. 2006. Metodología de la investigación. Mc Grawll Hill.

8) Secretaria de Educación Pública. (2015). Plan de Estudios. Educación Básica en México 2011. Secretaria de Educación Pública. 